\title{
COCCIDIOSIS IN SHEEP AND GOATS (REVIEW)
}

\author{
NADIA HAMID MOHAMMED; WASAN AMJAD ALOBAIDII \\ AND MANAL HAMMADI HASAN
}

Department of Microbiology, College of Veterinary Medicine University of Mosul, Mosul, Iraq

Received: 25 July 2021; Accepted: 30 August 2021

\begin{abstract}
Coccidiosis is an important diseases with economic impact to the small ruminants in the world, the main problem occurs in the young's animals. Species of Eimeria including Eimeria ovinoidalis, Eimeria ahsata and Eimeria bakuensis in sheep, and Eimeria arloingi, Eimeria ninakohlyaki movae and. Eimeria christenseni in goats. Clinical coccidiosis occurs mainly in the age 4-6 months, the main symptom is dehydration, as result of diarrhea, abdominal pain and weight loss, listlessness. Degree the tissue effect depend on the infection dose of oocysts, stress, species of Eimeria and factors related to the host such as age, genetic susceptibility and physical condition and degree of immune status of host, the most common gross lesions are thick in wall of the intestin and nodules formation. Therefore the aims of the review was to show the Eimeria species in sheep and goats and demonstrated history, classification, pathogenesis, life cycle, Epidemiology of parasite, clinical signs, diagnosis and treatment of coccidiosis.
\end{abstract}

Keywords: Eimeria species, coccidiosis in sheep, goats.

\section{INTRODUCTION}

Eimeria spp is protozoan parasites infects the small animals develop in the intestines of animals (Chartier and Paraud, 2012).

Eimeria is a serious disease of small animals and in different animal species in Iraq (AlAmery and Hasso, 2002) and in the world (Foreyt 1990). Coccidian are obligat disease that development in the cytoplasm epithelial cells caused the hyperplasia and death of that cell parasitized. (Koudela and Bokova, 1998).

Corresponding author: Wasan Amjad Alobaidii E-mail address: wasenamjad@yahoo.com

Present address: Department of Microbiology, College of Veterinary Medicine University of Mosul, Mosul, Iraq
The effects degree of tissue depends on size the infective dose of oocysts, species of Eimeria stress, and factors related to the host such as genetic susceptibility, age, degree of immunity of the host and physical condition. (Zhao et al., 2012).

Coccidia can damage intestinal cells of the host causing anemia and electrolytes loss (Callaghan et al., 1987). Several studies have found that the prevalence of coccidiosis in the sheep and goats were $85 \%$ or more, the high prevalence at time show the serious problem that this parasite poses and calls the need to its management proper (Woji et al.,1994) (Yun et al., 2000).

There are fifteen species of coccidian, Identified in sheep but three of them are serious pathogens and include E.bakuensis E.ovinoidalis and E.ahsata and while there 
16 type of coccidia in goats and most type pathogenic such as E.arloingi E.christenseni, E.caprina and E.ninakohlyakimovae (Catchpole et al., 1993) (Soulsby, 1982) (Constable et al., 2012) (khodakaram and hashemia, 2017).

\section{History}

Eimeria is a wide spread intestinal parasite in the world. Antony van leevween hook, he noticed the first oocysts of E. stiedai in the yellow channels of rabbit in 1674 (Clark and colwell., 1974).

The name Coccidia recorded in the first time in 1879 by lenckart. Researchers Moussu and Marotel in 1902 described the first species of Eimeria in the sheep it is E. faurei (Constable et al., 2012). In 1903, Minchin was able to classify coccidia by the number of sporocyst in the oocyst (Chhabra and Pandey., 1991).

The use of the electron microscopy by Grasse in 1953 has helped to add new information about the classification and life cycle of parasites (Wang et al., 2010).

\section{Classification of Parasite}

Coccidiosis is caused by small organisms belonging to the Eimeria species and has been classified as parasite based on (Taylor et al., 2007) reported as follows:

Kingdom: Protista

Phylum: Apicomplexa

Class: Sporozoa

Order: Eucoccidiorida

Suborder:Eimeriorina

Family: Eimeriidae

Genus: Eimeria

\section{Life cycle of Eimeria spp.}

Several studies have indicated that the Eimeria is an obligatory parasite that needs one host to complete its life cycle (Chhabra and Pandey, 1991). The parasite's life cycle begins when the animal eats food or water contaminated with the sporulated oocysts and when this reaches the small intestine
(Chartier and Paraud, 2012). The oocyst membrane ruptures the sporozoites escape to invade the epithelial cells of intestines and transfers into trophozoite and then to shizont (Clark and Colwell., 1974).

The schizonts consist of merozoites, which invade other epithelium of intestine result in secondary schizont and produce second merozoites by a sexual reproduction and the second generation merozoites intervention of epithelial cell of intestine to produce sexual reproduction to produce macro and microgamonts (gamogony) (Kusiluka and Kambarage, 1996).

The microgamete fertilize the macrogamete to produce the zygote (Lima et al., 1981). The zygote is surrounded by a wall to produce an oocyst. The oocyst is excreted with faeces of the host (Kusiluka et al., 1996).

The stages of parasite development in various intestinal regions, the prepatent period is 2-3 weeks when the suitable conditions are available under moisture, temperature $\left(23-34^{\circ} \mathrm{C}\right)$ (Lee et al., 2001).

\section{Epidemiology of parasite}

Several factors play an important role in the spread of the coccidiosis which cause economic losses in animals herds (Platzer et al., 2005) these include:

1- Animal factors:

Age is considered a major factor in severity of the infection. (Razavi and Hassanvand, 2007), severity and prevalence of the disease is high in the young ages and gradually decreases with the age of the animal (Reeg et al., 2005). (Arslan et al., 1999) reported that the prevalence of coccidia in Mosul city in small age sheep $(71.4 \%)$ while the prevalence of Eimeria in adult ages reaching (40\%) (Ali et al., 2005).

While the sex results showe no relationship between the sex of the sheep 
and the number of Eimeria oocyst with faeces (Ruiz et al., 2006).

(shmaon, 2005) showed that there are no difference in the incidence of female and male infestation $(84 \%$ and $90 \%$ respectively).

Also (Ali et al., 2005) in the Mosul city recorded $61.29 \%, 58.33 \%$ in male and female respectively. The state of pregnancy in the animal is one of the important in the incidence of disease epidemiology leads to the weakness of immunity in pregnant ewes thus increases the number of oocysts in the stool (Soe and pomroy 1992) (Faizal and Rajapakse, 2001).

2- Factors affecting epidemiology are the dose size of parasite oocysts taken by the animal and the parasite species (Altaf and Hidayatu, 2014).

3- Factors related to the environment such as temperature, oxygen tension, humidity (Hashemia et al., 2014) (Ruiz et al., 2012).

$\left(27-32^{\circ} \mathrm{c}\right)$ it is considered the ideal degree of sporulation of parasite (Silva et al., 2014).

4- Factors related to parasite transmission (Morrison et al., 2004).

\section{Prevalence of Coccidiosis}

Prevalence of coccidian has been reported in all world wide coccidia infected herds has been estimated at $50 \%$ in world throughout Europe, Asia, the middle South and East America (Koudela and Bokova,1998).

The prevalence rate of coccidiosis is higher during the rainy season because it is positively influenced by the warm and humid weather in the literature review various percentages of Eimeria spp have been recorded of sheep and goats in Iraq, There are $63.3 \%$ and 55.07 in Mosul province (Alani et al., 1989) (sullaman
2005). $72 \%$ in Sulaimaniya province (Kareem and Yuce 12015). 3.25 in Erbil province (Ahmed et al., 2015), 69.6\% in Baghdad (Kalef et al., 2013), 50\% and $57.5 \%$ in Wasit (Al-Rubaie and qaAlSaadon 2018), 86.09\% in Diyala (Minnat, 2014), 67.5\% in Al-Muthana (Mohammed 2013).

Recent studies in some countries such as Jordan (Abo-shehada and Abo-fareha2003), Turkey (Arslan et al., 1999), China (Wang et al., 2010), Iran (Kheirandish et al., 2014), Brazil (Amarante and Barbosa, 1992) have indicated that coccidiosis in sheep and goats are an important clinical and subclinical disease (Kumar et al., 2016).

\section{Pathogenesis:}

Eimeria spp parasites that obligate development in epithelial cells for the cytoplasm and produce cell death that infection with parasite and hyperplasia (Hatamnahavandi et al., 2016).

The severity infection has arelation with number of oocyst take by the animal and on the location of the parasite in the epithelial lining of the intestines Eimeria species Immune status and age of host and the stages of development in the various intestinal regions. (Mohamaden et al., 2018).

coccidia causes changes in the intestinal mucosa of infected animals causing localized hemorrhage and atrophy which results in decreased intestinal absorption (Kheirandish et al., 2014).

The developmemt of non-sexual stages lead to the destruction of epithetlial cells, destroy of capillaries of the mucosa in intestinal produce anaemia and hypoproteinaemia (Mohamaden et al., 2018).

The damage of mucosa in intestine causes diarrhea and dehydration. (Silva and lima, 1998).

\section{Clinical signs}

The incidence of Eimeria parasites is either 
acute or chronic, the case of acute the signs are diarrhea, which is a common symptom which may last for three days as well as weakness, loss of appetite abdominal pain, and weight loss, abdominal pain, diarrhea, tenesmus (Levine et al., 1985) (Sharma et al., 2017).

While in chronic infection the signs are general weakness weight loss and poor growth of the lambs (Deger et al., 2003).

The appearance of clinical signs depends on the type of coccidia and its location in the intestine, Genetic susceptibility, stress factors (Khodakaram and hashemnia, 2017) (Silva and lima, 1998).

\section{Diagnosis}

There are many laboratory tests that can be performed to confirm the diagnosis of coccidosis (taylor 2007):

1- Microscopy of faeces:

Identify of coccidia spp depends on size and shape of oocysts and morphology of sporocyst (Watson and Gill., 1991)

2- The development stages of Eimerai spp. demonstrated by Giemsa-stained and haematoxylin eosin stain (Mohammed 2012).

3- Post mortem examination (Altaf and Hidayatu, 2014)

4- Molecular diagnosis

Polymerase Chain Reaction is mutual molecular diagnostic method used to detection of Eimerai spp (Al-Rubaie and Al-Saadoon, 2018)

\section{Treatment and prevention of coccidiosis}

Researchers have found many preventive and curative measures to reduce the spread of coccidiosis in animals herds, the successful and economical prevention depends on avoiding animal overcrowding. (Balick and Ramisz, 1999).

The lambing and kidding grounds must as clean and dry in case of outbreaks in the herds, the infected animals should be isolated and given the anticoccidial drugs
(Cox 1998).

For treatment, there are many veterinary preparations used to treat the disease including decoquinate $0.5 \mathrm{mg} / \mathrm{kg} \quad \mathrm{B} . \mathrm{W}$, sulfonamides (Dominguez et al., 2001).

Diclozuril adose $1 \mathrm{mg} / \mathrm{kg}$ a mixed with sulfonamide and chlorlet racycline have give protection in lambs (Dai et al., 2006).

Also used the Amprolium in feed to treat the disease $100 \mathrm{mg} / \mathrm{kg}$ BW for 21 days (Constable et al., 2012).

\section{REFERENCE}

Abo- Shehada, MN. and Abo-Farieha, HA. (2003): Prevalence of Eimeria species among goats in northern Jordan Small Rumin Res; 49 (2): 109-13.

Ahmed, A.; Aziz, Kj. and Abdullah, So. (2015): Prevalence of gastro intestional nematodes parasites from sheep and evaluation of some anthelminthic resistance in Erbil. Governorate. Bas.j.vet. Res. 14(1): 111.

Al- Rubaie, HM. and Al-saadoon, ZM. (2018): Detection of Eimeria spp. of sheep in wasit province - Iraq journal of entomology and zoology studies. 6(2) 943-947.

Al-Amery, M.A.Y. and Hasso, S.A. (2002): Laboratory diagnosis of nove species of Theileria hirci, Eimeria caprovina and Eimeria pallida in goats in Iraq. Small Rumin. Res. 44, 163-166.

Alani, Aj.; Alousi, TI.; Al-Bayati, MM. and Hassan, MA. (1989): Vine coccidiosis in mosul, Iraq. J. Vet. parasitol. 3, 711.

Al-Bayati SM, Al-Rekani Am and Hamed A. (2016): Diagnosis of Eimeria Spp. In capra ibex (local meriz goat) the Iraqi journal of vet med. 40(1): 47-52.

Ali, M.M.; Suliman, E.G. and Mahmood A.F. (2005): Comparison study for incidence of Eimeria spp and cryptosporidium spp in sheep between 
mosul and Kirkuk .j.dohuk univ., 8(2):175-180.

Al-Saadoon, Zm. and Al-Rubaie, HM. (2018): Iraditional and molecular study for prevalence of coccidiosis in sheep in Wasit-Iraq. Indian journal of natural sciences., 8(49): 14396-14401.

Altaf, A.R. and Hidayatu, A. (2014): Study of some potential risk factors associated with coccidian in sheep $\mathrm{J}$. agr. Vet. Sci, 65-11-13.

Amarante, AF. and Barbosa, MA. (1992): species of coccidia occuring in lambs in sao Paulo state, brazil vet parasitol. 41 (3-4): 189-93.

Arslan, M.O.; Umur, S. and Kara, M. (1999): Te Prevalence of Coccidian Species in Sheep in Kars Province of Turkey. Trop. Anim. Health. Prod., 31,161-165.

Balicka-Ramisz, A. (1999): Studies on coccidiosis in goats in Poland. Vet. Parasitol., 81,347-349.

Callaghan, MG.; Douoghue, Pj. and Moore, E. (1987): coccidia in sheep in south Australia. Vet Parasitol. 24 (3-4): 17583.

Catchpole, J.; Norton, C.C. and Gregory, M.W. (1993): Immunization of lambs against coccidiosis. Vet. Rec. 132, 5659.

Chartier, C. and Paraud, C. (2012): Coccidiosis due to Eimeria in sheep and goats a review. Small Rumin Res 103 (1): 84-92.

Chhabra, R.C. and Pandey, V.S. (1991): Coccidia of goats in Zimbabwe. Vet. Parasitol. 39, 199-205.

Clark G.W. and Colwell D.A. (1974): Eimeria dalli sp. n. (Protozoa: Eimeridae) from Dall sheep Ovis dalli. J. Protozool. 21,197-199.

Constable, P.D.; Hinchcliff, K.; Done, S.H. and Grünberg, W. (2012): Veterinary medicine: a textbook of the diseases of cattle, sheep, pigs, goats, and horses, 11th edn, Elsevier Ltd., St. Louis,Missouri,pp401-408.

Cox, F.E. (1998): Control of coccidiosis: Lessons from other sporozoa. Int. J. Parasitol., 28, 165-179.
Dai, Y.B.; Liu, X.Y.; Liu, M. and Tao, J.P. (2006): Pathogenic effects of the coccidium Eimeria ninakohlyakimovae in goats. Vet. Res.Commun.30, 149160.

Deger, S.; Gul A.; Ayaz, E. and Bicek, K. (2003): The Prevalence of Eimeria Species in Goats in Van. Turk. J. Vet. Anim. Sci.27, 439-442.

Dominguez, E.; Perez, M.D.; Puyol, P.; Sanchez, L. and Calvo, M. (2001): Specifc immunoglobulins in serum of newborn lambs fed with a single dose of colostrum containing antiperoxidase, IgG. Res. Vet. Sci. 70,275-279.

Faizal, A.C.M. and Rajapakse, R.P.V.J. (2001): Prevalence of coccidia and gastrointestinal nematode infections in cross bred goats in the dry areas of Sri Lanka. Small Rumin. Res., 40, 233238.

Foreyt, Wj. (1990): Coccidiosis and cryptosporidiosis in sheep and goats. Vet Clin North Am Food Anim Pract. 6(3): 655-700.

Hashemia, M.; RezaeI, F.; Chalechale, A.; kakael, S. and Ghelchivand, S. (2014): prevalence intensity of Eimeria infection in sheep in western Iran. Int. J. livest. Res. 4: 107-112.

Hatamnahavandi, $\quad K$.; $\quad M a h v i, \quad A H$. ; mohebali, M.; keshavarz rezaei, S. and mirjalali, $H$. (2016): molecular typing of Eimeria ahsata and E-crandallis isolated from slaughter house waste water . Jundishapur J Microbiol. 9(4): 34-40.

Kalef, D.A.; Fadi, S.R. and Abbas, S.M. (2013): Occurance of Eimeria infection of sheep from Different regions of Baghdad city. Diyala $\mathrm{j}$ of agricultural sci. 5(1): 32-37.

Kareem, SI. and Yucel, SY. (2015): Prevalence of Eimeria species in sheep in sulaimaniya province Iraq. Journal of entomology and zoology studies. 3(4) 317-322.

Kheirandish, R.; Nourorah, SR. and yadegari, Z. (2014): prevalence and pathology of coccidiosis in goats in 
south eastern Iran J. parasitic dis, 2014, 38: 27-31.

Khodakaram, A. and Hashemnia, M. (2017): An overview of intestinal coccidiosis in sheep and goats. Revue med. Vet. 1(2), 9-20.

Koudela, B. and Bokova, A. (1998): coccidiosis in goats in the Czech republic. Vet parasitol. 76 (4): 261-7.

Kumar, B.; Maharana, BR.; Prasad, A.; Joseph, JP.; Patel, B. and Patel, JS. (2016): Seasonal incidenc of parasitic diseases in bovines of south western Gujarat (Junagadh), india, jparasit dis. 40(4): 1342-6.

Kusiluka, L. and Kambaraek, D. (1996): Disease of small ruminants, Easter, Bush, Scotland. pp87-90.

Kusiluka, L.J.M.; Kambarage, D.M.; Matthewman, R.W.; Harrison, L.J.S. and Daborn, C.J. (1996): Coccidiosis of small ruminants in Tanzania.Small Rumin.Res.21,127-131.

Lee, J.J.; Hutner, S.H. and Bovee, E.C. (2001): Te Illustrated Guide to the Protozoa, 2nd edn. Allen Press, Lawrence, KS,

Levine N.D.; Phylum, II.; Apicomplexa In: LEE J.J.; HUNTER, S.H. and BOVEE, E.C. (eds),(1985): An Illustrated Guide to the Protozoa, Allen Press, Lawrence. KS, pp 322-74.

Lima, J.D.; Levine, Ivens and Fritz (1981): Life cycle of Eimeria christenseni from the domestic goat, Capra hircus L. J. Protozool. 28,59-64.

Minnat, TR. (2014): detection of gastro intestional parasite infection of sheep and goats in Diyala procince - Iraq. Al- qadisiya journal of vet. Med. Sci. 13(2): 118-123.

Mohamaden, WI.; Sallam, NH. and Abouelhassan, EM. (2018): Prevalence of Eimeria species among sheep and goats in Suez Governorate, Egypt. International Journal of Vet Sci and Med. 6: 65-72.

Mohammed, MM. (2013): Serological study of sheep of coccidiosis in Al-Muthana. Kufa. J vet med sci, 4(1): 1-9.
Mohammed, N.H. (2012): Astudy on the pathological and diagnosis of Eimeria species infection in Japanese quail. BAS.J.VET.RES .11(1)318-333

Morrison, D.A.; Bornstein, S.; Thebo, P.; Wernery, U.; Kinne, J. and Mattsson, J.G. (2004): Te current status of the small subunit rRNA phylogeny of the coccidian (Sporozoa). Int. J. Parasitol. 34,501-514.

Platzer, B.; Prsol, H.; Cieslicki, M. and Joachin, A. (2005): Epidemiology of Eimeria infections in an Austrian milking sheep flock and control with diclazuril. Vet. Parasitol., 129, 1-9.

Razavi, S.M. and Hassanvand, A. (2007): A survey on prevalence of different Eimeria species in goats in Shiraz suburbs. J. Fac. Vet. Med. Univ. Tehran., 61,373-376.

Reeg, K.J.; Gauly, M.; Bauer, C.; Mertens, C.; Erhardt, $G$. and Zahner, $H$. (2005): Coccidial infections in housed lambs: oocyst excretion, antibody levels and genetic influences on the infection. Vet. Parasitol., 127,209-219.

Ruiz, A.; Gonzalez, J.F.; Rorderwz, E.; Martein, B.S.; Hernazez, Y.I.; ALmeid, A.R. and Molina, J.M. (2006): Influence of climatic and management factors on Eimeria infections in goats from semi-arid zones. J. Vet. Med.53, 399-402.

Ruiz, A.; Guedes, A.C.; Munoz, M.C.; Molina, J.M.; Hermosilla, C.; Martin, S.; Hernandez, Y.I.; Hernandez, A.; Perez, D.; Matos, L.; Lopez, A.M. and Tauber, A. (2012): Control strategies using diclazuril against coccidiosis in goat kids. Parasitol. Res.110, 21312136.

Sharma, DK.; Paul, S.; Rout, PK.; Mandal, A.; Bhusan, S.; Sharma, N. and Kushwah, YK. (2017): Caprine coccidiosis in semi-arid india: dynamics and factors affecting fecal oocysts count. Journal of Advanced Vet and Animal Research. 4(1): 52-57.

Shmaon, AA. (2005): Syrvey on Eimeria sp infecting sheep in the red sea state 
Eastern sudan .sudan MSC. thesis. Collage of Vet Sudan.

Silva, A.C. and Lima, J.D. (1998): Eimeria minasensis n. sp. (Apicomplexa: Eimeriidae) in the Domestic Goat Capra hircus, from Brazil. Mem. Inst. Oswaldo. Cruz. 93, 741-744.

Silva, L.M.R.; Vila-Vicosa, M.J.M.; Nunes, T.; Taubert, A.; Hermosilla, C. and Cortes, H.C.E. (2014): Eimeria infections in goats in Southern Portugal. Braz. J. Vet. Parasitol., 23, 280-286.

Soe, A.K. and Pomroy, W.E. (1992): New species of Eimeria (Apicomplexa: Eimeriidae) from the domesticated goat Capra hircus in New Zealand. Syst. Parasitol. 23, 195-202.

Soulsby, E.J.L. (1982): Helminthes, arthropods, protozoa of domesticated animals. $7^{\text {th }}$ ed. Baillier, tindal, London, pp: 430-431

Sullaman, E G. (2005): study of some eggs and oocystes of internal parasites in sheep in Mosul. Iraqi journal of vet. sci. 1(19): 21-32.

Taylor, M.A.; Coop, R.L. and Wall, R.L. (2007): Veterinary parasitology, 4ed Navarra, Spain75-78.
Wang, CR.; Xiao, Jy.; Chen, AH.; Chen, J.; Wang, Y. and Gao, Jf. (2010): Prevalence of coccidial infection in sheep and goats in north eastern china. Vet parasitol .174 (3-4): 213-7.

Wang, Y.; Gaoa, J.F. and Zhub, X.Q. (2010): Prevalence of coccidial infection in sheep and goats in northeastern China. Vet. Parasitol. 174, 213-217.

Watson, D.L. and Gill, H.S. (1991): Post natal ontogeny of immunological responsiveness in Merino sheep. Res. Vet. Sci. 51, 88-93.

Woji, A.Y.; Little, D.A. and Ikwaegbu, O.A. (1994): Prevalence of coccidial infection in the West African Dwarf goat in the sub-humid zone of Nigeria. Trop. Anim. Health Prod., 26, 1-6.

Yun, C.H.; Lillehoj, H.S. and Lillehoj, E.P. (2000): Intestinal immune responses to coccidiosis. Develop. Comp. Immunol., 24,303-324.

Zhao, GH.; Lei, LH.; Shang, CC.; Gao M.; Zhao, YG. and Chen, CX. (2012): High prevalence of Eimeria infection in diary goats in shaanxi province. north western china. Trop anim health prod. 44(5): 943-6.

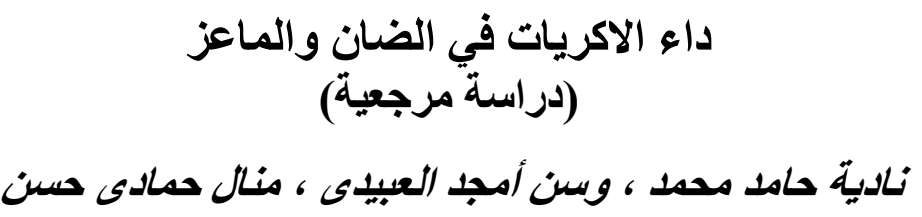

E-mail:wasenamjad@yahoo.com Assiut University web-site: www.aun.edu.eg

يعد داء الاكريات من الأمر اض المهمة ذات التأثير الاقتصادي على المجترات الصغيرة في العالم اذ يشكل هذا الداء مشكلة كبيرة في الحيو انات صغيرة السن. ومن أنواع الاكريات التي تصيب المجترات الصنات الصغيرة : Eimeria ovinoidalis

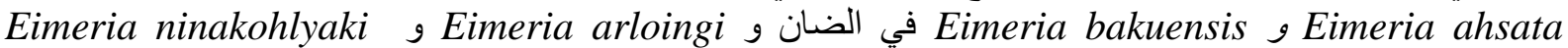
Eimeria christenseni و movae

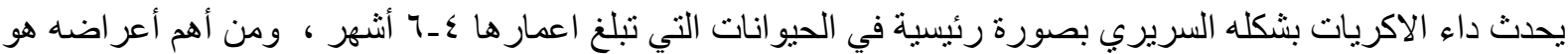

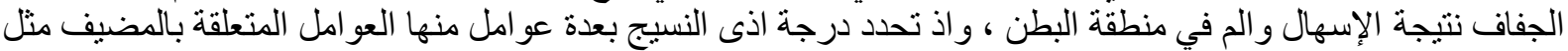

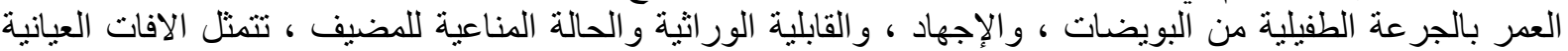

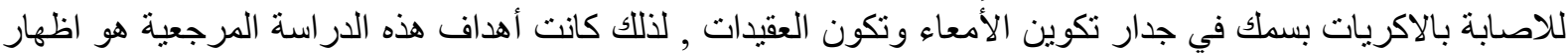

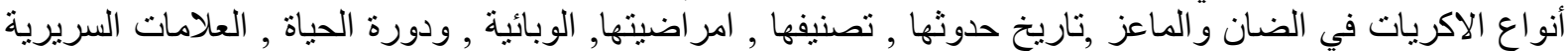
فضلا عن تشخيصا و علاجها.

$$
\text { الكلمات المفتاحية : انواع الاكريات , داء الاكريات , الضان , الماعز. }
$$

